\title{
Can Computer-Assisted Instruction Improve Students' Motivation and Academic Performance in Social Studies?
}

\author{
Danilo V. Rogayan Jr. ${ }^{1 *}$, May J. Padrique ${ }^{2,3}$, Joshua Costales ${ }^{2}$
}

\author{
${ }^{1}$ College of Teacher Education, President Ramon Magsaysay State University, PHILIPPINES \\ ${ }^{2}$ College of Teacher Education, President Ramon Magsaysay State University- Castillejos, Zambales, PHILIPPINES \\ ${ }^{3}$ Schools Division of Zambales, Department of Education, PHILIPPINES \\ *Corresponding Author: danrogayan@gmail.com
}

Citation: Rogayan, D. V. Jr., Padrique, M. J., \& Costales, J. (2021). Can Computer-Assisted Instruction Improve Students' Motivation and Academic Performance in Social Studies?. Journal of Digital Educational Technology, 1(1), ep2105. https://doi.org/10.21601/jdet/11334

\section{ARTICLE INFO}

Received: 25 Jul. 2021

Accepted: 28 Sep. 2021

\begin{abstract}
Teaching social studies requires more engaging and more student-centered strategies. The use of technology as pedagogy in this digital era is a typical picture in teaching social studies courses. Technology-integrated teaching is also a trend now due to educational disruption brought about by the COVID-19 pandemic. This one-group prepost-test action research investigated the effects of Computer-Assisted Instruction (CAI) on motivation and academic performance in social studies among students in a public secondary school in Zambales, Philippines. Findings revealed that the students had a fair level of motivation $(M=3.20)$ towards the subject before the intervention and had a high motivation ( $\mathrm{M}=3.59)$ after their exposure to CAI. The class had an average $(\mathrm{M}=23.18)$ academic performance in social studies before the intervention and had improved to above average (M=37.82) after the treatment. There was a significant difference in the motivation and academic performance of students after the application of the CAI. The study recommends the use of CAI in teaching select concepts in social studies to improve students' motivation and academic performance. Contextualization of CAI is also recommended specifically in this era of disruptive technologies and era of educational disruption.
\end{abstract}

Keywords: COVID-19 pandemic, disruptive technologies, educational disruption, educational technology, online teaching

\section{INTRODUCTION}

Social Studies (SS) is one of the most important courses in the basic education curriculum as it focuses on teaching the learners the sense of nationalism and the value of civic engagement. It is a discipline that pertains to the human relationship and the way society works (Crisolo et al., 2021). Furthermore, SS teaches the current generation of youth the necessary knowledge, skills, and attitude for them to be more cognizant and engaged in contemporary society. With the current COVID-19 pandemic that aggravated the volatile, uncertain, complex, ambiguous, diverse, and disruptive (VUCAD ${ }^{2}$ ) era (Crisolo et al., 2021), it is critical to teach the concepts of SS among the students.

The teaching of SS among generation $\mathrm{Z}$ learners (those born in 1995 to 2009) is essential; however, many teachers still struggle in finding out how to motivate students to engage actively in the course and eventually improve their academic performance. Recent literature revealed that some students have a disinterest in the course and find it boring (Ardyansah, 2021; Crisolo et al., 2021; Dinc \& Uztemur, 2017; Erol, 2021;
Kelley, 2021; Musselman et al., 2018; Rodriguez, 2019). Utilizing engaging and interesting pedagogical approaches in teaching Gen Z learners could increase the students' motivation and academic achievement in SS.

One of the innovative teaching approaches which can be used in teaching SS to Gen Z learners is Computer-Assisted Instruction (CAI). CAI is an appropriate and relevant approach as Gen $\mathrm{Z}$ learners are considered technology-savvy and digitally literate. CAI is defined as using computer technology to provide instructional materials and/or gauge student knowledge' (Pennington, 2010, p. 240). Further, CAI is the technological application to instruction and learning (Edyburn, 2013, p. 9). It can be utilized in all parts of the lesson, from motivation to content discussion and application to evaluation. CAI can be used through computer-based software such as MS PowerPoint or Prezi or delivered via mobile-based technologies. With the educational disruption brought about by the global pandemic, CAI can be an option to continue the education of learners in a distance learning mode.

Extensive scholarly literature showed the effectiveness of CAI as a teaching strategy (Adigun, 2020; Cassady et al., 2018; 


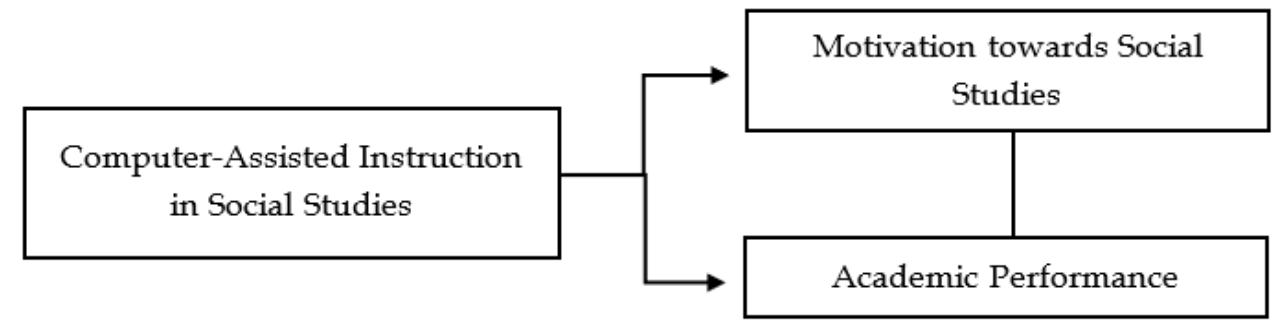

Figure 1. Diagrammatical framework of the study

Guo, 2018; Hawkins et al., 2017; Hendikawati et al., 2019; Kim et al., 2017; McKissick et al., 2018; Onah et al., 2020; Priskilla, 2018; Root et al., 2017; Syahmaidi et al., 2021; Tomesko et al., 2017; Ugwuanyi \& Okeke, 2020). Furthermore, several studies also revealed the effectiveness of CAI in SS instruction (Bariham, 2019; Bonsu et al., 2020; Ekpenyong \& Akwagiobe, 2018; Keane, 2018; Lawal \& Abdullahi, 2019; Nwaubani et al., 2014; Usman, \& Madudili, 2020). In the Philippines, CAI is also found useful in enhancing students' academic achievement (Rosali, 2020), enhancing comprehension (Kabigting, 2020), and being an effective tool for teaching (Marquez, 2017; Suson \& Ermac, 2020). However, the effects of CAI on students' motivation and academic performance in SS have not yet been thorughly investigated.

Hence, the present study focused its investigation on exploring CAI's effects on the students' motivation and academic performance in SS. The study was conducted in a face-to-face set up before the COVID-19 pandemic.

\section{Framework of the Study}

This study intended to examine the effectiveness of CAI on student motivation and academic performance in SS. Figure 1 shows the diagrammatical framework of the study.

CAI is a pedagogical strategy that makes use of computers and other digital infrastructures to deliver content to an individual or group of learners. CAI provides a customized, engaging, flexible, and adaptive learning experience to students. CAI can be used to enhance students' motivation and academic performance. CAI is also a mixture of self-learning principles with computer technology that students can use according to their learning speed (Kaleli, 2020).

Student motivation in SS can be intrinsic and extrinsic. In the present study, student motivation in SS is measured in terms of attitude, participation, homework, grades, and teacher's teaching style. Scholars have defined motivation in various ways. Motivation is the advancement and maintenance of goal-oriented behavior (Schunk, 2011), the learners' yearning and dynamism to study, work successfully, and reflect this enthusiasm and aspiration to achieve their full potential (Martin, 2016). It also affects the intensity and direction of wants and needs of an individual (Slavin, 2015).

Academic performance refers to the overall academic achievement of a learner based on his performance in the written works, performance tasks and quarterly examination.

\section{Purpose of the Study}

The study aimed to find out the effects of CAI on SS students' motivation and academic performance. The following research questions were answered:
1. What is the extent of students' motivation towards SS before and after the use of CAI?

2. What is the students' academic performance in SS before and after the use of CAI?

3. What is the students' performance in the formative assessment?

4. Is there a statistical difference in the mean scores of pretest and posttest in motivation and academic performance?

5. Is there a significant relationship between students' motivation and academic performance in social studies?

\section{METHODS}

\section{Research Design}

The study employed a within-group practical action research design in determining the effects of CAI on students' motivation and academic performance. It utilized the pretest and posttest as the main instruments in gathering the needed data. Formative assessments were likewise given to the students.

\section{Selection of Participants}

An intact class of 38 tenth-grade students in a state-owned secondary school in Zambales, Philippines, served as participants of this research. The class is comprised of 20 males and 18 females. Participants were between 15 to 17 years old and were residents of Castillejos, Zambales and nearby municipalities. Purposive convenience sampling was utilized to recruit participants for the study. The class was selected as it was handled by one of the researchers during her internship program and it is the best source of data based on the study's objectives. The study was conducted prior to the COVID-19 pandemic; hence, the intervention was applied during a faceto-face learning modality.

\section{Research Tools}

Instructional Plan. The study covered the lessons in the third quarter of Grade 10 economics: the Pagsusuri ng Ekonomiya: Makroekonomiks (Evaluating economic performance: Macroeconomics).

The study comprised of six modules which include lesson 1 (Paikot na Daloy ng Ekonomiya), lesson 2 (pambansang kita), lesson 3 (ugnayan ng pangkalahatang kita, pag-iimpok at pagkonsumo, lesson 4 (implasyon), lesson 5 (patakarang pisikal), and lesson 6 (patakarang pananalapi). 


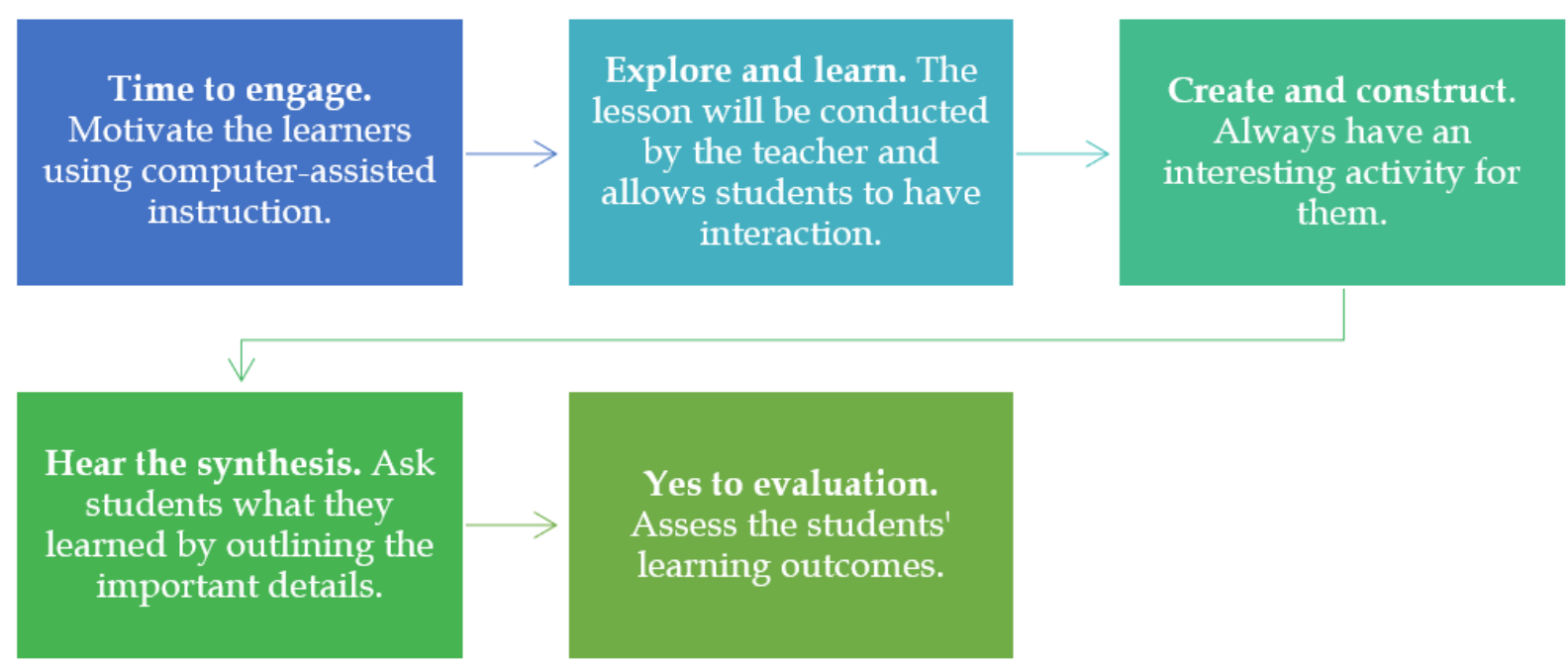

Figure 2. Steps of the Computer-Assisted Instruction

Social Studies Test. The SS test comprises 50 items based on Grade 10 SS curriculum guide. The exam underwent content validation by three experts in assessment and SS. Item analysis was made to gauge the reliability of the exam further.

The following rating scale for the test was used: 41-50 (excellent), 31-40 (above average), 21-30 (average). 11-20 (below average), and 1-10 (needs improvement).

Social Studies Motivation Scale. The SS Motivation Scale (SSMS) was patterned from the standardized and validated questionnaire of Russell and Hollander (1975). The descriptive rating for the motivational scale is as follows: very high (4.50 - 5.00), high (3.50 - 4.49), fair (2.50 - 3.49), low (1.50 - 2.49), and very low (1.00 - 1.49).

Formative Assessment Tools. The formative assessment tools were quizzes and activities and were rated according to the total number of correct answers. Activities were rated using rubrics.

\section{Data Gathering Procedure}

To have baseline data prior to treatment, the researchers administered a pretest to determine the students' motivation and academic performance. Following the pretest, the teacher provided instruction on the unit (Grade 10 economics) for six weeks. During the CAI application, the students' performances were assessed by means of quizzes and performance tasks. After exposing the students to CAI, the researchers administered the posttest. The results of the pretest and posttest was compared to ascertain the effects of the teaching strategy.

The intervention used in the study is CAI. The intervention was used three times a week for a duration of six weeks to check its effects on the motivation and academic performance of the students.

The steps in infusing the strategy were abbreviated as TECHY as shown in Figure 2.

\section{Data Analysis}

The statistical tools used in the analysis and interpretation of data and hypotheses testing were run through MS Excel ToolPack Kit 2013 and SPSS v. 20.
The frequency and percent distribution were used to compute the frequency counts and percent distribution of the students' test scores. The weighted mean was utilized to get the average of the scores and responses in the likert scale. The standard deviation was used to measure the spread of how far the observations are from their mean. The paired-samples $t$ test was utilized to know the statistical difference between the pretest and posttest scores. The Pearson Moment Correlation was used to investigate the correlation ( $r$ ) between academic performance and student motivation.

\section{RESULTS AND DISCUSSION}

\section{Students' Motivation towards Social Studies}

Table 1 shows the students' motivation towards SS before and after their exposure to CAI.

The motivation of the students towards SS was determined before the intervention. Their motivation towards SS was measured in terms of attitude, participation, homework, grades and teacher's teaching style.

Prior to the intervention, the students had a fair $(M=3.20$, $\mathrm{SD}=0.79$ ) motivation towards SS. Specifically, they had high motivation that SS teacher utilizes understandable resources $(\mathrm{M}=4.33)$. Likewise, the students love SS because it gives them opportunities to experiment, discover and explore things ( $M=4.12)$, and agree that their teacher presents the lesson in varied ways $(\mathrm{M}=4.12)$. This connotes that the role of teachers is very important in facilitating learning in a SS classroom. It is critical for teachers to develop localized, contextualized, and indigenized teaching materials that can further enhance students' learning. The course also enhances the higher-order thinking skills of the students. With SS courses, students enhance their civic competence and understanding of the society they live in to become prolific and responsible community members (Crisolo et al., 2021). Teachers need to be critical thinkers in this society and should replicate this role to their students and the public in general (Rogayan \& Dantic, 2021). 
Table 1. Descriptive statistics of students' motivation towards Social Studies

\begin{tabular}{|c|c|c|c|c|}
\hline \multirow{2}{*}{ Statements } & \multicolumn{2}{|c|}{ Before } & \multicolumn{2}{|c|}{ After } \\
\hline & Mean & DR & Mean & DR \\
\hline \multicolumn{5}{|l|}{ A. Attitude } \\
\hline 1. I am always excited to attend my SS class this school year. & 3.86 & High & 4.30 & High \\
\hline 2. SS is fun and interesting. & 3.86 & High & 4.47 & High \\
\hline 3. I hate SS, it is not important for me. & 1.98 & Low & 2.42 & Low \\
\hline 4. I don't like SS at all. It is difficult to learn. & 2.05 & Low & 2.77 & Fair \\
\hline 5.I love SS, it gives me opportunities to experiment, discover and explore the things around me. & 4.12 & High & 4.53 & Very High \\
\hline \multicolumn{5}{|l|}{ B. Participation } \\
\hline 1. I'm always prepared in my SS class. & 3.63 & High & 4.16 & High \\
\hline 2. I participate actively in SS activities by asking questions. & 3.67 & High & 4.28 & High \\
\hline 3. I do my SS assignments consistently. & 3.65 & High & 3.81 & High \\
\hline 4. SS activities do not help me understand concepts easily. & 2.30 & Low & 2.42 & Low \\
\hline 5. I feel bored in my SS class. & 2.49 & Low & 2.70 & Fair \\
\hline \multicolumn{5}{|l|}{ C.Homework } \\
\hline 1. I complete my SS homework on time. & 3.63 & High & 3.86 & High \\
\hline 2. I find homework very useful and important. & 3.84 & High & 4.33 & High \\
\hline 3. SS homework is difficult to do. & 2.67 & Fair & 2.93 & Fair \\
\hline 4. I don't get enough support to do my homework at home. & 2.84 & Fair & 2.91 & Fair \\
\hline 5. My teacher does not check my homework at all. & 1.91 & High & 2.65 & Fair \\
\hline \multicolumn{5}{|l|}{ D. Grades } \\
\hline 1. I got good grades in SS. & 3.91 & High & 4.16 & High \\
\hline 2. I study my lessons before a test or quiz. & 3.58 & High & 4.09 & High \\
\hline 3. The terms/words used in the test are difficult to understand. & 2.72 & Fair & 3.26 & Fair \\
\hline 4. The test always measures my understanding of SS concepts and knowledge learned. & 3.74 & High & 3.88 & High \\
\hline 5. The grading is not fair. & 2.19 & Low & 2.72 & Fair \\
\hline \multicolumn{5}{|l|}{ E. Teacher's Teaching Style } \\
\hline 1. I have a good relationship with my SS teacher. & 3.88 & High & 4.23 & High \\
\hline 2. My SS teacher uses materials that are easy to understand. & 4.33 & High & 4.51 & Very High \\
\hline 3. My SS teacher presents the lesson in a variety of ways. & 4.12 & High & 4.30 & High \\
\hline 4. I don't understand the way my SS teacher explains the lesson. & 2.16 & Low & 2.49 & Low \\
\hline 5. I don't get any feedback about my understanding of the lesson from my SS teacher. & 2.88 & Fair & 3.33 & Fair \\
\hline Overall & 3.20 & Fair & 3.59 & High \\
\hline
\end{tabular}

Legend: Very High, 4.50 - 5.00; High, 3.50 - 4.49; Fair, 2.50 - 3.49; Low, 1.50 - 2.49; Very Low, 1.00 -1.49; DR-Descriptive Rating

Meanwhile, Grade 10 students disagreed that they did not understand the way their teacher explains the topic $(\mathrm{M}=2.16)$ and that the teacher does not give feedback on their homework $(\mathrm{M}=1.91)$. This suggests that students are motivated when a teacher explains the lesson well and when homework is given appropriate feedback. Teachers' emotions impact teachers' and learners' cognition, motivation and behaviors (Buric \& Moe, 2020). Therefore, it is very important for teachers to undergo professional development activities to further enhance their technological pedagogical content knowledge (TPACK).

The study results imply that prior to the students' exposure to the intervention, they had a fair motivation in the course.

After the application of CAI, the class had a high ( $M=3.59$, $\mathrm{SD}=0.77$ ) motivation towards SS. The majority of the class strongly agreed that they love SS because it gives opportunities to them to experiment, discover, and explore things $(\mathrm{M}=4.53)$. The students also agree that they are always prepared in the class ( $M=4.16)$ and likewise got good grades in SS $(M=4.16)$. SS give opportunities to students to think critically, probe systematically and investigate judiciously the things that they see, feel and witness in society. After the intervention, students became more prepared in their SS course and obtained higher grades. The degree of integration of CAI is ascertained through the interplay between digital infrastructure, teachers' and learners' attitudes and perspectives, teacher motivations, innovations and development of online pedagogies and content (Barihaman, 2019).

On the other hand, the following statements obtained the lowest means in the post-intervention: "SS activities do not help me understand concepts easily" $(\mathrm{M}=2.42)$ and "I hate SS, it is not important for me" $(\mathrm{M}=2.42)$. These negative statements suggest that students believe that the learning tasks provided by the teacher in a technology-directed environment helped them retain the concepts better. They also developed a better perspective on the importance of SS in their studies and in understanding society better. SS allow the learners to be more mindful and responsive to civic issues and conflicts and take the right action towards an improved and more inclusive community (Crisolo et al., 2021).

Generally, the motivation level of the students towards SS had improved with the use of the teaching strategy. It connotes that CAI had a significant impact in enhancing students' motivation towards SS. This is consistent with the results of previous studies on the effectiveness of CAI in improving students' motivation (Adara \& Haqiyah, 2021; Ajam et al., 2021; Chekour, 2017; Dordevic, 2020; Doster \& Cuevas, 2021; Hannel \& Cuevas, 2018; Kaleli, 2020; Sharma, 2017; Stelea \& Girón-García, 2017). 
Table 2. Descriptive statistics of the students' pretest and posttest scores

\begin{tabular}{ccccc}
\hline \multirow{2}{*}{ Score } & \multicolumn{2}{c}{ Pretest } & \multicolumn{2}{c}{ Post-test } \\
\cline { 2 - 5 } & Frequency $(\mathbf{N}=\mathbf{3 8})$ & Percent (100.0) & Frequency (N=38) & Percent (100.0) \\
\hline $41-50$ & 0 & 0.00 & 22 & 34.21 \\
\hline $31-40$ & 2 & 5.26 & 3 & 7.52 \\
\hline $21-30$ & 24 & 63.15 & 0 & 0.00 \\
\hline $11-20$ & 12 & 31.57 & $\mathbf{3 7 . 8 2}$ (Above Average); SD = 4.75
\end{tabular}

Legend: Excellent, 41-50; Above Average, 31-40; Average, 21-30; Below Average, 11-20; Needs Improvement, 1-10

Table 3. Quizzes of Grade 10 students

\begin{tabular}{ccccc}
\hline Quizzes & Items & Mean & SD & Mean Percent Score \\
\hline Quiz A & 15 & 11.18 & 2.68 & 74.53 \\
\hline Quiz B & 15 & 13.77 & 2.21 & 91.79 \\
\hline Quiz C & 10 & 9.85 & 0.53 & 98.46 \\
\hline Quiz D & 10 & 9.90 & 0.44 & 98.97 \\
\hline Quiz E & 10 & 10.00 & 0.00 & 100.00 \\
\hline
\end{tabular}

Table 4. Performance tasks of Grade 10 students

\begin{tabular}{cccc}
\hline Performance Tasks (PT) & Mean & SD & Mean Percent Score \\
\hline PT 1 & 18.34 & 1.67 & 91.71 \\
\hline PT 2 & 20.79 & 4.22 & 83.16 \\
\hline PT 3 & 15.61 & 2.22 & 78.03 \\
\hline PT 4 & 2.29 & 2.13 & 89.16 \\
\hline
\end{tabular}

Academic Performance of Students before and after the Application of CAI

A 50-item pretest was administered to assess the academic performance of the SS students. The class and individual performances were described by using the percent and frequency counts. The item analysis was also used to evaluate the strengths and weaknesses of the students.

The pretest results were tabulated to determine the students' academic performance before the application of the strategy (Table 2).

The pretest results showed that the class performed to an average level in academic performance as shown in the overall mean of 23.16 . Only $5.26 \%$ of the class was above-average level; most of the students were classified in the average (63.15\%) and below-average (31.57\%) level. None of the students belonged to the excellent level and needs improvement level prior to treatment. Before the intervention, the level of academic performance of the class is considered average.

The posttest results showed that the class improved to the above-average level in academic performance, as shown by the overall mean of 37.82 . A total of $34.21 \%$ of the class belonged to the excellent level, $60.52 \%$ to an above-average level, and $7.89 \%$ to the average level. None of the students belonged to the below-average and needs improvement levels. This connotes that the use of CAI had improved the students' academic performance in SS.

The results of the study conform to the findings of the previous studies that CAI is a helpful tool in increasing students' academic performance (Bonsu et al., 2020; Ekpenyong \& Akwagiobe, 2018; Keane, 2018; Lawal \& Abdullahi, 2019; Nwaubani et al., 2014; Raghaw et al., 2018; Usman, \& Madudili, 2020; Wahyuni, 2016; Xefteris et al., 2019).

\section{Students' Performance in the Formative Assessment}

To gain more insights, formative assessments were also given to the participants in terms of quizzes (Table 3).

The results of the quiz scores are considered above average during the intervention as shown by the mean percent score in five quizzes. The CAI significantly improved students' performance in the formative assessment. CAI integration into classrooms should complement, rather than substitute, conventional teacher-focused strategies to content delivery (Kaye \& Ehren, 2021).

Table 4 shows the performance tasks scores of the students.

The students' performance tasks also recorded a favorable trend and was considered above average. It is significant to note that the computer-assisted instruction facilitated an improvement in the class performance. While ensuring teachers are properly oriented for their role in CAI interventions is essential, understanding whether learners have the ability to use the tools is also equally important (Kaye \& Ehren, 2021).

Difference on the Motivation and Academic Performance of Students

The significant difference on the students' motivation was also determined (Table 5).

The table showed a mean gain of 0.39 from the preassessment mean score of 3.00 and the post-assessment mean score of 3.59. This means that there was an improvement in the students' motivation towards SS after exposing them to the CAI. The $t$-value of 5.487 and the p-value of 0.000 obtained imply a statistical difference in the motivation pretest and posttest of Grade 10 students. It means that the application of CAI affects the motivation of the students towards SS. It connotes that the CAI helps the students enhance their 
Table 5. Paired samples T-test of the pre-assessment and post-assessment mean scores in SSMS

\begin{tabular}{cccccc}
\hline Post-assessment Mean Pre-assessment Mean & Gain Score & $\boldsymbol{t}$-value & $\boldsymbol{p}$-value & Remarks \\
\hline 3.59 & 3.20 & 0.39 & 6.038 & $\mathrm{p}<0.5$ & Significant \\
\hline Significant at $p<.05$ & & & &
\end{tabular}

Table 6. Paired samples T-test of the Pretest and Post-test Mean Scores in the Achievement Test

\begin{tabular}{cccccc}
\hline Posttest Mean & Pretest Mean & Gain Score & $\boldsymbol{t}$-value & $\boldsymbol{p}$-value & Remarks \\
\hline $\mathbf{3 7 . 8 2}$ & 23.18 & 14.63 & 17.590 & $\mathrm{p}<0.5$ & Significant \\
\hline
\end{tabular}

Significant at $p<.05$

Table 7. Correlation between motivation and academic performance in SS

\begin{tabular}{cccc}
\hline Variable & r & p & Remark \\
\hline Motivation and Academic Performance & 0.117 & 0.482 & No Significant Correlation \\
**. Correlation is significant at the 0.01 level (2-tailed) & & &
\end{tabular}

motivation in learning the course. The effect size of 0.23 (Cohen's d) suggests a small magnitude of effect.

The results align with previous research indicating that CAI can improve students' motivation (Adara \& Haqiyah, 2021; Ajam et al., 2021; Doster \& Cuevas, 2021).

To determine the change in the academic performance of the class before and after the application of the CAI, a t-test table is presented (Table 6).

The table showed a gain score of 14.63 from the pretest mean score of 23.18 and posttest mean score of 37.82 . It indicates that there was an increment in the achievement of the Grade 10 students exposed in the computer-assisted instruction. The $t$-value of 17.590 and the $p$-value of 0.000 was obtained with the use of $t$-test of paired-samples. It means that the application of CAI affects the academic performance of the students. It connotes that the CAI helps the students to improve their performance in the subject. The effect size of 0.85 (Cohen's $d$ ) suggests a large magnitude of effect.

The results are similar to the findings of previous studies that CAI has a significant impact on the students' academic achievement (Kaye \& Ehren, 2021; LeJeune \& Lemons, 2021; Lestari \& Thresia, 2021).

\section{Relationship between Motivation and Academic Performance}

The significant relationship between motivation towards SS and academic performance of students is presented (Table 7).

The results showed that motivation had no significant correlation with academic performance, with a correlation coefficient of $0.117(\mathrm{p}<0.482)$. This finding implies that there exists no significant relationship between the two variables.

In-class activities and interactions enhance the degree or frequency of student interactions, which positively impacts students' motivation in learning (Bergmann \& Sams, 2016). In the study, it was found that motivation and academic performance are not significantly correlated. This is supported by previous studies (Arulmoly \& Branavan, 2017; Yamin et al., 2021; Zhang, 2021). However, the study results negate the findings of previous studies stating that there is a significant relationship between motivation and academic achievement (Liu et al., 2020; Pascoe et al., 2018; Tripathi et al., 2018).
Teachers are challenged to improve the students' digital literacy, which is one of the core skills they need to have as they hurdle the challenges of the current educational landscape and the fourth industrial revolution or FIRe (Baterna et al., 2020). Further, it is a must for $21^{\text {st }}$-century teachers to have computer skills to cope up with the needs of $21^{\text {st }}$-century learners (Paje et al., 2021). With the utilization of CAI, this challenge can be surmounted.

\section{CONCLUSIONS}

The study aimed to assess the use of CAI in enhancing students' motivation and academic performance in social studies (SS). Before the application of CAI, the motivation of the Grade 10 towards SS was fair. After the intervention, their motivation towards the subject had improved. Before the intervention, the students are in the average level of academic performance. After the intervention, the students' academic performance in SS had improved. There was a statistical difference in the students' motivation and academic performance scores after their exposure to CAI. There was no significant correlation between motivation and academic performance in SS. The results suggest that CAI can really improve the students' motivation and academic performance in SS. Despite these significant results, there is a need for a continuous study focused on the use of assessment for this objective and identifying other variables that contribute to the effectiveness of CAI.

\section{RECOMMENDATIONS}

The use of CAI in teaching social studies may be encouraged. Teachers must utilize it in teaching select concepts in SS courses to improve students' motivation and academic performance. Since CAI enhanced students' motivation and academic performance, the local government leaders, private entities, and other education stakeholders may provide computers and other digital infrastructures in schools to better implement the strategy. Curriculum planners may consider curriculum review of SS in the junior secondary schools to incorporate the CAI techniques in the instructional process. Contextualization of CAI is also recommended specifically in this era of disruptive technologies and era of 
educational disruption. With the current COVID-19 pandemic, teachers may also consider migrating the conventional use of CAI in the classroom to the current modalities of learning which are online synchronous and online asynchronous. Since the action research is limited only to one Grade 10 section in one school, it is recommended to include more classes and other grade levels in future studies. Future studies may consider longer duration of the strategy since the study only lasted for two months to look into the long-term effects of using CAI. For the next cycle of action research, the gaps and problems identified in the application of the strategy may be given attention and proper action. Conduct of similar study during an educational disruption may be considered.

Author contributions: All co-authors have involved in all stages of this study while preparing the final version. They all agree with the results and conclusions.

Funding: No external funding is received for this article.

Acknowledgments: The researchers would like to thank President Ramon Magsaysay State University for the support, the Schools Division of Zambales and the selected school for the approval to conduct the study, and the Grade 10 students for their assent and active engagement. To the editor and external reviewers for the insightful comments which improved this research article.

Declaration of interest: The authors declare that they have no competing interests.

Ethics approval and consent to participate: Not applicable. Availability of data and materials: All data generated or analyzed during this study are available for sharing when appropriate request is directed to corresponding author.

\section{REFERENCES}

Adara, R. A., \& Haqiyah, A. (2021). Improving Indonesian EFL learners' motivation through computer assisted learning (CALL). Journal of English Language Studies, 6(1), 110-121. https://doi.org/10.30870/jels.v6i1.9119

Adigun, O. T. (2020). Computer-assisted instruction, project based learning and achievement of Deaf learners in Biology. Journal of e-Learning and Knowledge Society, 16(1), 23-32.

Ajam, A., Balulu, N., Purnomo, E., \& Daud, A. (2021). Use of computer assisted instruction to improve students' comprehension on syntax. Humano: Jurnal Penelitian, 12(1), 1-10.

Ardyansah, N. (2021). Improving active questioning and learning outcomes on social studies through make a match learning model in Class IX C SMP N 7 Purwokerto in the first semester of the academic year 2014/2015. Forum Ilmu Sosial, 48(1), 85-92. https://doi.org/10.15294/fis.v48i1. 25174

Arulmoly, C., \& Branavan, A. (2017). The impact of academic motivation on student's academic achievement and learning outcomes in mathematics among secondary school students in Paddiruppu Educational Zone in The Batticaloa District, Sri Lanka. International Journal of Scientific and Research Publications, 7(5), 115-126. https://doi.org/10.5958/2249-7137.2017.00046.5
Bariham, I. (2019). Influence of teachers' gender and age on the integration of computer assisted instruction in teaching and learning of social studies among basic schools in tamale metropolis. Global Journal of Arts, Humanities and Social Sciences, 7(2), 52-69.

Baterna, H. B., Mina, T. D. G., \& Rogayan, D. V. Jr. (2020). Digital literacy of STEM senior high school students: Basis for enhancement program. International Journal of Technology in Education, 3(2), 105-117. https://doi.org/10.46328/ijte.v3i2.28

Bergmann, J., \& Sams, A. (2016). Flipped learning for elementary instruction (Vol. 5). International Society for Technology in Education.

Bonsu, N. O., Bervell, B., Kpodo, E., Arkorful, V., \& Edumadze, J. K. (2020). Computer-assisted instruction in the teaching and learning of history: A systematic review in Africa. Computer, 14(9), 584-605.

Buric, I., \& Moe, A. (2020). What makes teachers enthusiastic: The interplay of positive affect, selfefficacy and job satisfaction. Teaching and Teacher Education, 89, 103008 https://doi.org/10. 1016/j.tate.2019.103008

Cassady, J. C., Smith, L. L., \& Thomas, C. L. (2018). Supporting emergent literacy for English language learners with computer-assisted instruction. Journal of Research in Reading, 41(2), 350-369. https://doi.org/10.1111/14679817.12110

Chekour, A. (2017). The effectiveness of computer-assisted math instruction in developmental classes. AURCO Journal, 23(Spring), 21-30.

Crisolo, O. R., Camposano, S., \& Rogayan, D. V. Jr. (2021). Relevance of social studies in the 21st century society: Students' perspectives. International Journal of Didactical Studies, 2(1), 101457. https://doi.org/10.33902/IJODS. 2021169729

Dinc, E., \& Uztemur, S. (2017). Investigating student teachers' conceptions of social studies through the multidimensional structure of the epistemological beliefs. Educational Sciences: Theory \& Practice, 17(6), 2093-2142. https://doi.org/10.12738/estp.2017.6.0429

Dordevic, J. (2020). Improved understanding of meanings of modal verbs in legal English and increased motivation through computer assisted language learning. Ibérica: Revista de la Asociación Europea de Lenguas para Fines Específicos, 39, 295-317.

Doster, H., \& Cuevas, J. (2021). Comparing computer-based programs' impact on problem solving ability and motivation. International Journal on Social and Education Sciences, 3(3), 457-488. https://doi.org/10.46328/ ijonses. 121

Edyburn, D. L. (2013). Critical issues in advancing the special education technology evidence base. Exceptional Children, 80, 7-24. https://doi.org/10.1177/001440291308000107

Ekpenyong, E. E., \& Akwagiobe, A. B. (2018). Unmasking the effectiveness of computer assisted instruction in the teaching and learning of social studies in Cross River State College of Education Akamkpa, Cross River State, Nigeria. Global Journal of Arts, Humanities and Social Sciences, 6(7), 45-52. 
Erol, H. (2021). Views of social studies teachers on e-learning. International Education Studies, 14(6), 82-91. https://doi.org/10.5539/ies.v14n6p82

Guo, H. (2018). Application of a computer-assisted instruction system based on constructivism. International Journal of Emerging Technologies in Learning, 13(4), 33-44. https://doi.org/10.3991/ijet.v13i04.8468

Hannel, S. L., \& Cuevas, J. (2018). A study on science achievement and motivation using computer-based simulations compared to traditional hands-on manipulation. Georgia Educational Researcher, 15(1), 4055. https://doi.org/10.20429/ger.2018.15103

Hawkins, R. O., Collins, T., Hernan, C., \& Flowers, E. (2017). Using computer-assisted instruction to build math fact fluency: An implementation guide. Intervention in School and Clinic, 52(3), 141-147. https://doi.org/10.1177/ 1053451216644827

Hendikawati, P., Zahid, M. Z., \& Arifudin, R. (2019). Androidbased computer assisted instruction development as a learning resource for supporting self-regulated learning. International Journal of Instruction, 12(3), 389-404. https://doi.org/10.29333/iji.2019.12324a

Kabigting, R. P. (2020). Computer-assisted instruction and students' comprehension of a literary text. Journal of English Language Teaching and Applied Linguistics, 2(2), 4047.

Kaleli, Y. S. (2020). The effect of computer-assisted instruction on piano education: an experimental study with preservice music teachers. International Journal of Technology in Education and Science, 4(3), 235-246. https://doi.org/10.46328/ijtes.v4i3.115

Kaye, T., \& Ehren, M. (2021). Computer-assisted instruction tools: a model to guide use in low-and middle-income countries. International Journal of Education and Development using Information and Communication Technology, 17(1), 82-99.

Keane, R. V. (2018). The effects of computer assisted instruction for students with learning disabilities in a self-contained social studies setting [Master's thesis, Rowan University]. Rowan Digital Works. https://rdw.rowan.edu/etd/2560/

Kelley, C. (2021). "Social studies is boring”: The role of student attitude and achievement in the middle school social studies classroom [Doctoral dissertation, Ohio Dominican University]. OhioLINK. http://rave.ohiolink.edu/etdc/ view?acc num=oduhonors1620144135878313

Kim, M. K., McKenna, J. W., \& Park, Y. (2017). The use of computer-assisted instruction to improve the reading comprehension of students with learning disabilities: An evaluation of the evidence base according to the what works clearinghouse standards. Remedial and Special Education, 38(4), 233-245. https://doi.org/10.1177/ 0741932517693396

Lawal, U. S., \& Abdullahi, Y. (2019). Effect of computer assisted instruction on teaching of self reliance skills for sustainable entrepreneurship development among undergraduate social studies students in Kaduna State. African Journal of Inter/Multidisciplinary Studies, 1(1), 6172. https://doi.org/10.51415/ajims.v1i1.809
LeJeune, L. M., \& Lemons, C. J. (2021). The effect of computerassisted instruction on challenging behavior and academic engagement. Journal of Positive Behavior Interventions, 23(2), 118-129. https://doi.org/10.1177/1098300720929680

Lestari, A. W., \& Thresia, F. (2021). The effect of computer assistant instruction (CAI) on advanced reading. Intensive Journal, 4(1), 27-36.

Liu, Y., Hau, K. T., Liu, H., Wu, J., Wang, X., \& Zheng, X. (2020). Multiplicative effect of intrinsic and extrinsic motivation on academic performance: A longitudinal study of Chinese students. Journal of Personality, 88(3), 584-595. https://doi.org/10.1111/jopy.12512

Marquez, L. V. (2017). Development of computer assisted instruction (CAI) in college statistics. The Normal Lights, 11(2), 180-207.

Martin, A. J. (2016). The motivation and engagement workbook (16th ed.). Lifelong Achievement Group. www.lifelongachievement.com

McKissick, B. R., Davis, L. L., Spooner, F., Fisher, L. B., \& Graves, C. (2018). Using computer-assisted instruction to teach science vocabulary to students with autism spectrum disorder and intellectual disability. Rural Special Education Quarterly, 37(4), 207-218. https://doi.org/10.1177/ 8756870518784270

Musselman, A., Hess, M. E., \& Lowery, C. L. (2018). Gaming in the social studies classroom: Student perceptions of learning history with mobile media. Journal of Research Initiatives, 4(1), Article 10. https://digitalcommons.uncfsu. edu/jri/vol4/iss1/10

Nwaubani, O. O., Okafor, O. S., \& Onyeanusi, O. C. (2014). Teachers' perception of the effectiveness of computerassisted-instruction in the teaching of junior secondary school social studies in Nnewi Education Zone, Anambra State, Nigeria. Journal of Education and Practice, 5(29), 155164.

Onah, E. N., Ugwuanyi, C. S., Okeke, C. I., Nworgu, B. G., Agwagah, U. V., Ugwuanyi, C. C., Obe, P. I., Nwoye, M. N., \& Okeke, A. O. (2020). Evaluation of the impact of computer-assisted instruction on mathematics and physics students' achievement: Implication for industrial technical education. International Journal of Engineering Research and Technology, 13(7), 1786-1794. https://doi.org/10.37624/ ijert/13.7.2020.1786-1794

Paje, Y. M., Rogayan, D. V. Jr., \& Dantic, M. J. P. (2021). Teachers' utilization of computer-based technology in science instruction. International Journal of Technology in Education and Science, 5(3), 427-446. https://doi.org/ 10.46328/ijtes.261

Pascoe, L., Spencer-Smith, M., Giallo, R., Seal, M. L., GeorgiouKaristianis, N., Nosarti, C., Josev, E. K., Roberts, G., Doyle L. W., Thompson, D. K., \& Anderson, P. J. (2018). Intrinsic motivation and academic performance in school-age children born extremely preterm: the contribution of working memory. Learning and Individual Differences, 64, 22-32. https://doi.org/10.1016/j.lindif.2018.04.005 
Pennington, R. C. (2010). Computer-assisted instruction for teaching academic skills to students with autism spectrum disorders: A review of the literature. Focus on Autism and Other Developmental Disabilities, 25, 239-248. https://doi.org.10.1177/1088357610378291

Priskilla, M. (2018). Interactive multimedia based on computer assisted instruction: development efforts on the learning interest and effectiveness in the history learning. International Journal of Humanities and Social Science, 5(6), 43-47. https://doi.org/10.14445/23942703/ijhss-v5i6p108

Raghaw, M., Paulose, J., \& Goswami, B. (2018). Augmented reality for history education. International Journal of Engineering \& Technology, 5, 1-5. https://doi.org/10.14419/ijet.v7i2.6.10136

Rodriguez, J. (2019). Perceptions and practices of US preservice special education teachers on teaching social studies instruction in inclusive classrooms. International Journal of Inclusive Education, 25(8), 928-943. https://doi.org/10.1080/13603116.2019.1590472

Rogayan, D. V. Jr., \& Dantic, M. J. P. (2021). Backliners: Roles of science educators in the post-COVID milieu. Aquademia, 5(2), ep21010. https://doi.org/10.21601/aquademia/11053

Root, J. R., Stevenson, B. S., Davis, L. L., Geddes-Hall, J., \& Test, D. W. (2017). Establishing computer-assisted instruction to teach academics to students with autism as an evidence-based practice. Journal of Autism and Developmental Disorders, 47(2), 275-284. https://doi.org/ 10.1007/s10803-016-2947-6

Rosali, L. J. D. (2020). Effect of computer-assisted instruction (cai) on the academic achievement in secondary physics. Open Access Library Journal, 7(5), 1-11. https://doi.org/10.4236/oalib.1106319

Russell, J., \& Hollander, S. (1975). A biology attitude scale. The American Biology Teacher, 37(5), 270-273. https://doi.org/10.2307/4445229

Schunk, D. H. (2011). Learning theories: An educational perspective ( $6^{\text {th }}$ ed.). Pearson.

Sharma, R. (2017). Computer assisted learning-A study. Computer, 4(2), 102-105.

Slavin, R. E. (2015). Cooperative learning in elementary schools. Education 3-13: International Journal of Primary, Elementary and Early Years Education, 43(1), 5-14. https://doi.org/10.1080/03004279.2015.963370

Stelea, S., \& Girón-García, C. (2017). Computer-assisted instruction: 'JClic' as a new pedagogical tool for EFL learners. International Journal of Education and Development using ICT, 13(1), 4-31.

Suson, R., \& Ermac, E. (2020). Computer aided instruction to teach concepts in education. International Journal on Emerging Technologies, 11(3), 47-52.
Syahmaidi, E., Hidayat, H., Hartanto, S., \& Rahmadani, A. F. (2021, February). Designing e-training computer assisted instruction used to pedagogic competency in vocational education. In Journal of Physics: Conference Series (Vol. 1779, No. 1, p. 012038). IOP Publishing. https://doi.org/10.1088/1742-6596/1779/1/012038

Tomesko, J., Touger-Decker, R., Dreker, M., Zelig, R., \& Parrott, J. S. (2017). The effectiveness of computer-assisted instruction to teach physical examination to students and trainees in the health sciences professions: a systematic review and meta-analysis. Journal of Medical Education and Curricular Development, 4, 2382120517720428. https://doi.org/10.1177/2382120517720428

Tripathi, A., Chaturvedi, K. R., \& Tripathi, A. P. (2018). Assessing the influence of intrinsic motivation on academic performance: A study of management teachers. Pertanika Journal of Social Sciences \& Humanities, 26(3), 1455-1470.

Ugwuanyi, C. S., \& Okeke, C. I. (2020). Enhancing university students' achievement in physics using computer-assisted instruction. International Journal of Higher Education, 9(5), 115-124. https://doi.org/10.5430/ijhe.v9n5p115

Usman, Y. D., \& Madudili, G. C. (2020). Assessment of the impact of computer assisted instruction on teaching and learning in Nigeria: A theoretical viewpoint. International Journal of Education and Development using Information and Communication Technology, 16(2), 259-271.

Wahyuni, S. (2016). Development of computer assisted instruction (CAI) based teaching materials in junior high school. International Journal of Learning and Teaching, 2(2), 117-120. https://doi.org/10.18178/ijlt.2.2.117-120

Xefteris, S., Palaigeorgiou, G., \& Tsorbari, A. (2019). A learning environment for geography and history using mixed reality, tangible interfaces and educational robotics. In M. E. Auer, \& T. Tsiatsos (Eds.), The challenges of the digital transformation in education (pp. 106-117). Springer International Publishing. https://doi.org/10.1007/978-3030-11935-5_11

Yamin, G., Khalid, H., Tahir, F., Khatri, E., \& Shoaib, S. (2021). The effect of academic background on social competence and its relationship with academic motivation and academic performance of first year university students. Sukkur IBA Journal of Educational Sciences and Technologies, 1(1), 16-28. https://doi.org/10.30537/sjest.v1i1.713

Zhang, M. Y. (2021). The relationship among TCSL teachers' self-efficacy, students' learning motivation, and academic performance. US-China Education Review, 11(1), 30-34. https://doi.org/10.17265/2161-623x/2021.01.004 